\title{
Education as an Instrument of Poverty Eradication in Kenya: Successes and Challenges
}

\author{
Josephine Oranga $\mathbb{}^{\circledR}$, Enock Obuba ${ }^{\circledR}$, Eliud Nyakundi \\ Kisii University, Kenya \\ Email: josephineoranga@kisiiuniversity.ac.ke, enockobuba@kisiiuniversity.ac.ke, eliudnyakundi@kisiiuniversity.ac.ke
}

How to cite this paper: Oranga, J., Obuba, E., \& Nyakundi, E. (2020). Education as an Instrument of Poverty Eradication in Kenya: Successes and Challenges. Open Journal of Social Sciences, 8, 410-424. https://doi.org/10.4236/jss.2020.89031

Received: July 22, 2020

Accepted: September 26, 2020

Published: September 29, 2020

Copyright $\odot 2020$ by author(s) and Scientific Research Publishing Inc. This work is licensed under the Creative Commons Attribution International License (CC BY 4.0).

http://creativecommons.org/licenses/by/4.0/

\begin{abstract}
Studies show that increased access to education can contribute to economic growth and poverty eradication. Accordingly, acquired basic skills such as reading, writing and numeracy have a positive effect on marginalized populations' incomes and the rate of return on the economy. The wish to eliminate poverty in Kenya has been articulated since independence through a number of enactments and policy papers. However rampant poverty still abounds. Abject poverty threatens access to essential services by about $38 \%$ of Kenyans living below the poverty line. In its effort to combat poverty, the government introduced free primary and free day secondary education with poverty alleviation as one of its objectives. However, the free basic education has so far not eliminated poverty as envisaged due to a number of challenges. This paper thus presents the successes, failures and challenges of the free basic education in Kenya against the need for it to help eliminate poverty by thematically examining and analysing literature. From the analysis, the successes include: increased school enrolment, reduction in illiteracy levels, improved transition rates to secondary school, eradication of child labour, improved assessment and placement of learners with disabilities and abandonment of harmful traditional practices. The challenges include: understaffing, massive unplanned expansions of schools, inability of parents to provide subsistence, the quality issue and delayed funds disbursement amongst others, thereby rendering education unable to efficiently play its role in poverty alleviation. Recommendations are thereafter given.
\end{abstract}

\section{Keywords}

Basic Education, Poverty Alleviation, Transition Rates, Kenya, Infrastructural Improvements 


\section{Introduction}

A report by the World Bank (2018), indicates that the prevalence of poverty in Kenya remains relatively high as compared to other lower and middle income countries despite the proportion of Kenyans living on less than the international poverty line (US1.90 per day in 2011) having declined from $43.36 \%$ in 2005/2006 to $35 \%$ in 2015/2016 (World Bank, 2018).

The report further indicates that the agricultural production sector has been the key driver of poverty reduction in Kenya implying that the education sector so far has not played its rightful role in poverty eradication as envisioned in the Poverty Reduction Strategy Paper (PRSP, 2003; PRSP, 2005) in which education was mentioned as a would-be driver of economic growth and poverty reduction. This, subsequently, led to the introduction of free primary and free day secondary education whose goals included, fighting illiteracy, bridging the gap between the rich and the poor, creation of an informed citizenry capable of participating actively in the nation's economic development, elimination of child labour, elimination of school dropout rates and boosting of the girl child's education (Mulanda \& Kosea, 2018 and Mulinya \& Orodho, 2015, PRSP, 2003). Furthermore, studies indicated that the vast majority of countries in the Sub-Saharan Africa region were at risk of not attaining universal primary school completion by the year 2015 (Carceles, Fredriksen, \& Watt, 2001), hence the concerted effort towards the introduction free basic education in the region.

As early as 1965, the government of Kenya recognized poverty together with illiteracy and disease as the major constraints to human socio-economic development. Subsequently, a number of strategies, policies and plans were developed and adopted all geared towards alleviating poverty, the plans included: The National Poverty Eradication Plan (NPEP, 1999), Participatory Poverty Assessment Reports (PPARs, 1999) and the Interim Poverty Reduction Strategy Paper (IPRSP, 2000). However, Gregoire (2017), reports that only 30 people are pulled out of poverty every hour in Kenya, apparently, making Kenya a poor performer in comparison to Ethiopia which pulls 300 out of poverty per hour.

Education for All Global Monitoring Report (EFA, Global Monitoring Report, 2013) indicates that education not only helps people escape poverty by imparting knowledge and developing the skills that people need to improve their livelihoods, but also helps to generate productivity gains that fuel and enhance economic growth. More so, education helps individuals realise and nurture their potentials leading to innovation, creativity or gainful employment thereby leading to socio-economic stability. Accordingly, while economic growth does not automatically reduce poverty, without it, sustained poverty reduction is not possible. Statistics show that for every US $\$ 1$ spent on education, between US $\$ 10$ and US $\$ 15$ would be generated in economic growth (EFA, Global Monitoring Report, 2013).

A good education system is expected to respond to the social, economic and political objectives of a country (Rono, 2015; Muteshi, 2016). Accordingly, education contributes to worthwhile economic growth by increasing the efficiency 
of the labour force, enhancing the creation of better technology, improving and creating better products and services, and in the process reducing poverty and improving standards of living (Mueni and Macho, 2016; UNESCO, 2020). Subsequently, economic growth is expected to translate into higher well distributed incomes, consequently, lowering poverty levels in households and communities. Apparently, the more educated the citizenry are, the more productive they are in the households and labour market. Thus, imparting compulsory, quality education to the citizenry is beneficial and is expected, in the long run, to lead to poverty alleviation. Studies (Aseyo, 2015; Muteshi, 2016; Musomi, 2018) have shown that investment in primary education has a higher rate of economic return as compared to secondary education. This paper focuses on the successes and challenges facing the basic education subsector as a whole (primary and secondary) in its endeavour to help alleviate poverty with specific reference to Free Primary and Free Day Secondary education introduced in Kenya in 2003 and 2008 respectively.

African countries are expected to double or triple the number of primary school graduates due to the success of the universal primary education system under the Education for All (EFA) programs (Bregman \& Stallmeister, 2002; Lewin, 2004). However, according to the authors, the existing secondary schools in the vast majority of African countries lack the structural capacity to absorb this increase. Avenstrup, Liang, and Nallemann (2004) indicate that the abolition of primary school fees in Sub Saharan Africa has resulted in unprecedented massive increase in enrolment. Accordingly, when Uganda introduced free Uganda Primary Education (UPE) in 1997, it experienced a 68 percent increase in overall enrolment from 3.4 million to 5.7 million in one year. Moreover, according to Deininger (2003), the huge increase in primary enrollments in the country was amongst girls and the rural poor. Accordingly, 46 percent of learners aged $6-12$ from the poorest households were enrolled in primary education against 82 percent of children from the richest quintile in 1992. However the figures improved by 1997 with 78 percent of children from the poorest quintile being enrolled in primary schools as compared to 89 percent of children from the rich households (Deininger, 2003). Of great significance was the gains made in enrolment of girls from the poorest households. The author, too revealed that the general glaring gender bias in access and retention of girls at school that had existed prior to the scrapping of school fees had literally disappeared, giving credence to the significance of free basic education in increasing access and retention of learners and more so girls, from marginalized and economically constrained communities.

In Kenya, transition to secondary schools increased gradually after the introduction of free primary school, however following the introduction of free secondary school in 2008, the transition rate to secondary schools increased significantly. For instance, the Gross Enrolment Rate (GER) and the Net Enrolment Rate (NER) improved from a low of 28 percent and 19.4 percent, respectively in 2005 to 38 percent and 24.2 percent in 2007 respectively before registering an 
even more significant increment of 45.3 percent and 35.8 percent in 2009, respectively. Accordingly, there is a need to sustain these positive trends in order to meet manpower requirements, as well as standards for a rapidly industrializing nation such as Kenya (Republic of Kenya, 2010; Hannon, 2012). However, sustenance would require urgent and corresponding expansion of physical and structural facilities, abolition of other related school levies and provision of more teachers (Mulinya \& Orodho, 2015). Consequently, this paper explores the extent to which the Kenyan Government policy changes in the basic education subsector, specifically through the introduction of free primary and free day secondary education, has contributed towards economic development and poverty reduction, amongst its citizenry in the last decade. Firstly, the paper examines the extent to which free primary and free day secondary education policy in Kenya has succeeded in socio-economically empowering and reducing poverty amongst the citizenry and secondly describes the barriers and challenges encountered by the education subsector in its endeavour to provide free primary and free day secondary education, whose long term goals include poverty alleviation. The challenges by extension stand in the way of poverty alleviation. It is expected that the understanding of these successes and challenges will lead to the re-evaluation of the manner of implementation, building on the successes and seeking solutions to the challenges. It is also expected that this will be vital information to stakeholders in pursuit of the global aim of Education for All (EFA).

\section{Methodology}

Relevant literature review and analysis enabled thematic interpretation and understanding of the extent to which education has played a role in socio-economic development and poverty reduction in Kenya. Electronic data bases, institutional websites and journals were searched in an attempt to gather relevant information. This paper thus, presents the successes and challenges encountered by the main stakeholders and players in the education sub-sector in their endeavour to implement free basic education (free primary and free day secondary education) aimed at alleviating poverty, in the long run, in Kenya.

\section{The Successes}

Rono (2015) indicates that there are successes and socio-economic justifications for investment in free primary and free day secondary education in Kenya in view of the objectives for which both free primary and free day secondary education were initiated and implemented. The objectives of free primary and free day secondary education in Kenya as earlier stated include poverty alleviation and economic growth. Accordingly, the challenges encountered in the implementation of free primary and secondary education in Africa, are commonly associated with socioeconomic failures and setbacks, consequently, making the realization of the Education for All (EFA) in Kenya and the entire African conti- 
nent a daunting challenge. Thus, in light of the high social and private returns to investment in primary and secondary education (Psacharopoulos and Patrinos, 2002), practical and innovative policy strategies and interventions are urgently needed to improve the quality of primary and secondary education and meet the increasing need for the same without disregarding the basic requirements for the success of free education programmes in Africa (Aseyo, 2015). In light of the analysed literature, the following emerged as the successes of free primary and free day secondary education in Kenya, thus:

\subsection{Increased Enrolment/Reduced Illiteracy Levels}

The introduction of free primary and free day secondary education has been marked by gradual yearly increase in enrolment since its implementation in 2003. A large percentage of students who were hitherto school-excluded due to financial constraints are now getting a chance at education. This is in line with world statistics which indicate that in 2014, nearly 4 million more children were enrolled in primary schools than they were in 2003 in the world. Apparently, literacy levels have also increased substantially. UNESCO (2017) reports that overall illiteracy levels in Kenya are amongst the lowest in sub-Saharan Africa. Accordingly, youth literacy rates amongst persons aged between $15-24$ years in Kenya are at $87 \%$ with free primary education being the main player (UNESCO, 2017). It is noteworthy that free primary education and free day secondary education were implemented in 2003 and 2008 respectively in Kenya. The enhanced enrolment and improved literacy rates are expected to gradually result in a citizenry that are critical thinkers, creative and knowledgeable. Their innovations would solve societal problems and create employment leading to sustained economic development.

The increased enrolment is also partly due to the enrolment of mature students who missed a chance at basic education at the appropriate age due to inability to raise school fees and other levies charged by primary schools then. This, thus, reveals the extent to which primary school fees and other levies charged by schools can be prohibitive and only serve to deny a significant number of children a chance at basic education (Mulanda and Kosea 2018; UNICEF, 2009). The predicament of the mature learners served to emphasise further, the significance of basic knowledge and skills, like reading and writing, easily gained at the primary school level. Apparently, these skills are essential in running smallholder business enterprises and daily errands. This goes a long way towards demonstrating the importance of free basic education to the citizenry of a nation, more so, a developing one.

\subsection{Improved Transition to Secondary Schools}

Ohba (2012) reports that previously the primary school system in Kenya was characterised by high wastage in the form of low enrolment, high dropout rates, repetition of grades and so on. The transition rate to secondary school has significantly improved since the introduction of free primary education. Statistics 
from the year 2016 show that the net enrolment rate in secondary school was $53.1 \%$ up from $28.9 \%$ in 2008 . Evidently, the transition rate has been rising gradually due to the high number of students enrolled in primary schools who subsequently transit to secondary schools (MoEST, 2018). Thus, free primary education has, to a given extent, reversed the previous negative trends. Available statistics from the year 2014 to 2018 show an already improved transition rate, increasing gradually yearly, thus (Table 1).

Table 1. Transition rate to secondary school between years 2014 to 2017 .

\begin{tabular}{cc}
\hline Year & Transition Rates \\
\hline 2014 & $80.4 \%$ \\
2015 & $81 \%$ \\
2016 & $82.05 \%$ \\
2017 & $84 \%$ \\
\hline
\end{tabular}

Source: Ministry of Education Science and Technology (MoEST, 2018) in prime.org.

Moreover, the government policy on achieving $100 \%$ transition from primary to secondary school is vigorously being enforced. The legislation that makes it criminal to fail to attend school when one is of school going age has enforced this rule further. It is expected by the year 2021, all the pupils who do the transiting examinations from primary to the secondary level, Kenya Certificate of Primary Education (KCPE) and who get assigned secondary schools by the government will report as assigned. Therefore, as mentioned, improvement in transition rates has had implications on the literacy levels of the citizenry and is expected to translate into an informed population that is creative to not only seek employment, but run various personal businesses and innovations that earn them a living, thus reducing poverty and contributing to economic development.

\subsection{Eradication of Child Labour in Poor Urban and Rural Settings}

Mueni and Macho (2016) indicate that free primary education has led to the eradication of child labour. Children in poor rural and urban households were hitherto "leased out" out to richer families at a monthly fee. These children (some of whom were as young as 6 years) were expected to work as child minders, herds-boys, firewood collectors and water-fetchers for richer families who would by then, have sent all their children to school with no one left behind to run their errands (Onyango, 2017 and Ngugi, 2013). Hence, the alternative was to employ children from poor families who would not afford to go to school. Free primary education rendered this practise criminal as the government mandated all children of school going age to attend school free of charge and village headmen tasked with ensuring that no child of school going age was left behind in their areas of jurisdiction. Forthwith, it became criminal to employ children of school going age as child minders, herds-boys or housemaids. It is envisaged that if the practise of taking all children to school is sustained, a large percentage 
of the citizenry would be educated resulting in a population of knowledgeable and innovative persons who can become key drivers of economic growth and poverty elimination. UNESCO (2017) indicates that education is vital for escaping chronic poverty and perpetuation and transmission of poverty between generations.

\subsection{Improved Assessment and Placement of Learners with Disabilities (LWDs)}

Persons with disabilities in Africa form a big percentage of those who are school excluded and as a result, they are amongst those that live in dire socioeconomic circumstances due to little government support and lack of employment. Most of them do not transit to higher education due to several constraining factors including financial and social (Mwangi, 2013; MoE, 2009). However, free primary and free day secondary education in Kenya's has led to improved formative assessment and placement of learners with disabilities (LWDs). The government, through the village headmen, ensures that all children of school going age, regardless of whether or not they have a disability, are enrolled at the nearest public schools (Nduka, 2015; Musomi, 2018). Special units for LWDs attached to local primary schools have thus, increased 5 fold, which is quite phenomenon, considering that Special Units for learners with disabilities were hitherto a reserve of just a few chosen primary schools, rendering most LWDs unable to access them due to the long distances they would have to cover in order to reach school, coupled with other economic constraints. Currently, special units are attached to several primary schools in all localities in Kenya and cater for learners who cannot benefit from the mainstream classroom due to one kind of disability or another (Mwangi, 2013; MoE, 2009). Having LWDs enroll at school is empowering on its own as schooling is expected to prepare them for the labour market, subsequently, increasing their participation in the country's socio-economic development and poverty alleviation efforts. Furthermore, the policy that requires that all public institutions be accessible and responsive to the needs of persons with disabilities has ensured that schools, to a given extent, are inclusive and easily accessed by all persons with disabilities (Mulanda and Kosea, 2018).

\subsection{Abandonment of Harmful Traditional Practices}

According to Lucas \& Isaac (2012), the free education in Kenya is a welfare project that has increased enrolment in public schools, reduced enrolment in the fairly expensive private schools and provided access to education by the disadvantaged citizens who could otherwise have dropped out or never bothered to enroll thereby exposing them to harmful cultural practices. Consequently, the increased enrolment in primary and secondary schools has limited the rate of exposure of school going children to adverse traditional practices. For instance, free primary education has rendered traditional Female Genital Mutilation 
(FGM) practitioners with fewer children to conduct the harmful practise on, thus, compelling them to embrace more progressive and beneficial employment alternatives. Mulanda and Kosea (2018) indicate that communities that practised early marriages and female genital mutilation have discarded the practise due to the emphasis that the government of Kenya and civil societies have placed on the education of the girl child, and strengthened further by the introduction of free primary and free day secondary education. Early marriages previously contributed to high school dropout rates amongst the vast majority of girls in arid and semi-arid area of Kenya. This has, however, reduced considerably with the introduction of free primary and free day secondary school (Mulanda \& Kosea, 2018). Moreover, the logic behind the practise of FGM was to prepare young girls for marriage and as such once the girls underwent FGM, they were deemed ready for marriage, the fact that very young girls (as young 11 years old) were subjected to it, notwithstanding. The vast majority of the girls now spend most of their time at school, leaving less time for traditional practices. A vast majority of children also get to learn about the adverse effects of the cultural practices at school and shun them (Mulanda \& Kosea, 2018). This is in line with Rawat (2017), who indicates that educational levels and economic status of women in developing countries are directly associated with mutilation practices, with FGM less likely to be found among higher educated women. Additionally, UNESCO (2020), reports that giving girls access to schooling is a central part of eradicating female genital mutilation. Accordingly, educating girls also gives them the freedom to make decisions to improve their lives. Furthermore, according to Rawat (2017), educated young men also help question the rationale behind the archaic traditions and reinforce the arguments against them, giving rise to stronger societies. Additionally, learning to read and write can create confidence in young people and the need to challenge inequality in society. Moreover, illiteracy and low levels of education are a significant risk factor in perpetuating and experiencing intimate partner violence and the practice of FGM which are all detrimental to sustainable economic development (UNESCO, 2020).

\subsection{Government Funding of School Projects}

\subsubsection{School Projects}

According to Lucas \& Isaac (2012), of the Kenya Shillings (KES) 22,500 fees the government pays for each secondary school student, KES. 6000 is automatically set aside for the schools' infrastructural development. Initially, before the introduction of free primary education and free day secondary education, all infrastructural development projects were funded by unevenly distributed bursaries, levies and fundraisers. The setting aside of this amount has eased parents' financial burdens, consequently making free education totally free. At the inception of free basic education, the funds provided by the government were grossly insufficient (KES. 10,500) compelling schools to seek alternative ways of funding infrastructural projects. According to Orodho, Getange \& Onkeo, 2014, the government has since more than doubled the funding to the current KES. 22,500 and 
instituted stringent measures of adherence to the expenditure vote heads in an effort to make free basic education feasible and effective. Consequently, no construction or infrastructural levies and costs are met by parents. This is a significant social-economic benefit of free primary and free day secondary education.

\subsubsection{Free School Textbook and Equipment}

Apart from infrastructural development levies, parents were also expected to meet the cost of school learning materials including books and laboratory equipment at the inception of the free primary education programme (Orodho, Getange \& Onkeo, 2014). These costs proved prohibitive and reduced the gains made. Some parents opted to withdraw their children from schools due to the huge amounts they were required to pay. The levies were also unregulated and varied greatly amongst schools.

The new government policy has made and termed the levies towards books and other facilities illegal, subsequently retaining many children at school and thereby, making free basic education more accessible and impactful. Currently, the government supplies textbooks and other learning resources at the beginning of each year, and has given sufficient budgetary allocation for the purchase of laboratory equipment, the whole process of which is properly monitored and audited. It is worth noting that initially the provision of text books and other learning materials was the parents' prerogative, most of whom could not afford (Lucas \& Isaac, 2012).

Coupled with the above is the scrapping of examination fees by the government of Kenya in 2018. Examination levies had, hitherto, been a hindrance to the realisation of free basic education. It was a mandatory for parents to meet the cost of examinations taken at the end of the various levels of education in Kenya (Liang et al., 2004). The parents, most of whom were already financially constrained, struggled to raise the examination levies. However, the current government policy, which is already operational, stipulates that all students shall be given a national examination free of charge at the end of primary and secondary school levels. This is a huge milestone considering that many parents could not raise the examination fees. This is expected to further enhance retention and transition rates to high school and eventually, to higher educational institutions.

\section{The Challenges}

Despite the aforementioned successes, serious challenges have bedevilled and marked the implementation of the free primary education policy in Kenya (UNICEF \& World Bank, 2005). In the same vein, UNESCO (2005) decries the rush in implementing free primary education in Kenya without proper planning resulting in myriad challenges. Mulinya and Orodho (2015), however, indicate that, this has been the case in the vast majority of developing countries. The challenges threatening the free primary and free day secondary education policy in Kenya are discussed thematically as follows: 


\subsection{Understaffing in Public Schools}

Extremely high enrolment in some areas, especially urban areas, worsened the problem of staffing in a country that had staffing problems since independence (Ngugi, 2013; Musomi, 2018). It should however be noted that the government of Kenya trains a large numbers of teachers most of whom have remained unemployed for long periods of time due to perpetual budgetary deficits that render the Ministry of Education unable to employ enough teachers even as the teacher shortage continues to bite (Mutua \& Ochieng, 2018). As a result, there are several thousand unemployed trained teachers, yet schools continue running with less staff. The teacher shortage in schools has become so severe that the government recently announced plans to employ a few hundred thousand teachers as interns to help alleviate the teacher shortage while also ensuring that the government wage bill does not increase substantially (Gueye \& Gauci, 2011). Accordingly, their salary would be one third of a fully employed government teacher despite the fact that the work load would be the same or even much more. This beats the very logic behind free primary and free day secondary school education as the teachers will not be well motivated to work as their well remunerated counterparts on permanent employment, the fact that they have the same qualifications, notwithstanding. This consequently interferes with the long term goal of poverty alleviation function of education in Kenya. The teacher shortage problem could easily be solved if the government employed the teachers it trains and remunerates them accordingly, without bias.

\subsection{Massive Unplanned Expansions of Schools}

Free Primary Education was hurriedly implemented and has so far resulted in a huge, unplanned expansion of the primary school system in Kenya (Nduka, 2015). This has subsequently put a lot of pressure on structural and physical resources. Overcrowding has been widely reported in urban public schools with classes meant to accommodate 80 students having to accommodate up to double the number and still handled by the same teachers. This aspect of free primary education interferes with the quality of education provided as overworked teachers might not be productive. Furthermore, the teachers are unable to provide individualised learning that is required by most learners (Rono, 2015; Musomi, 2018). The teacher might also never know his/her students as should be the case. Malenya (2008) and Echessa (2017) contend that the demands of large class sizes with diverse needs preclude much individual attention. Thus, the overcrowding in classes totally interferes with the essence of learning, leading to poor learning outcomes. This would in turn hamper the envisaged economic empowerment of the families which is a vital component of poverty alleviation (MoEST, 2015).

\subsection{The Quality Issue}

Nations that provide free access to quality education to their citizenry are far 
more likely to reduce poverty and promote economic growth (United Nations, 2013; Hannon, 2012; Mulinya and Orodho, 2015). However in Kenya, crowded classrooms and extreme pressure on physical and human resources have gradually diluted standards in public schools to the extent that there is a general feeling that private schools, some of which are quite costly, offer better quality education as compared to public schools (Kisinya, 2016 and Fielden, 2011). This has interfered with the envisaged hope that quality and appropriate education would be provided that would subsequently result in a citizenry that is knowledgeable and innovative who would in turn be creative, and critical thinkers, resulting in poverty alleviation in the long run. This has prompted financially able parents to withdrew their children from public schools and enroll them in private ones, consequently, leaving the substandard, strained education systems to the poor, thereby helping perpetuate the cycle of poverty as learning outcomes in the public schools might not necessitate transition to higher education and the job market appropriately. According to Isaacs (2002), there should be a commitment by African governments to increase access and improve the quality of primary and secondary education through expansion of facilities.

\subsection{Parental Inability to Provide Subsistence}

Onyango and Muteshi (2016) indicate that there still exist constraints that hinder children from poorer households from transiting to higher levels even though the transition rates appear to have improved. Despite the introduction of free primary education and free day secondary education, other requirements, provisions and levies expected of parents for their children to join school cost about 3 times the average monthly income in Kenya (Onyango \& Muteshi, 2016). Parents are still expected to meet the costs of their children's school uniforms, food, transport, and other subsistence most of which are beyond the means of many parents in the rural and poor urban areas. Despite the promise of a free primary education in 2003 and free day secondary school in 2008, these subsistence costs have proven prohibitive to many families. Consequently, poor parents keep their children at home despite the much hyped about free primary education and free day secondary education because of the severe economic constraints they face (Akoojee \& McGrath, 2016). For such parents then, poverty reduction and bridging the gap between the poor and the rich is not their experience. It is estimated that a total of one million children, most of whom come from marginalized, rural areas and urban poor are still school-excluded due to the aforementioned reasons (Aseyo, 2015). It is for the same reasons also, that parents in most urban poor and rural areas are choosing to withdraw their young children from Early Years Education Centres (Early Childhood Centres) and keeping them at home till they reach the age of primary school entry (UNESCO, 2014). Evidently, this negates all the gains made by the free primary education programme in Kenya. Hence, there is need for the government to provide subsistence and other requirements for children from extremely poor families in order to keep them at school. 


\subsection{Underfunding/Delayed Funds Disbursement}

Extreme delays in disbursement of funds to primary and secondary schools by the government has been a major obstacle in the implementation of free primary and free day secondary education in Kenya (UNESCO, 2005; UNICEF and World Bank, 2005). There have been complaints and threats of total shut down of school functions due to extreme delays in releasing free primary education funds. In extreme cases, the schools are forced to arbitrarily imposed levies on parents in order to cushion themselves against imminent collapse of administrative functions. When the levies are imposed on parents, many learners are subsequently sent home due to inability to settle them. The decisions by the schools to impose levies are usually done unilaterally without the government's approval; however none of these schools have been reprimanded (Aseyo, 2015; Mueni and Macho, 2016). Hence, for schools to play their rightful role in economic development and poverty alleviation, consolidated and definitive planning structures should be put in place to ensure timely disbursement of funds. Only then can education systems retain students and reduce dropout rates, eventually leading to an educated and enlightened population, in general. An educated and enlightened population would be innovative and creative and able to seek and create meaningful employment opportunities, consequently resulting in reduced poverty rates and enhanced economic development.

\section{Conclusion and Recommendations}

\subsection{Conclusion}

The main challenges identified are: understaffing in public schools, the quality issue, requirement for parents to provide subsistence, and massive unplanned expansions of primary and secondary schools. Thus, as much as free primary and free day secondary education has been implemented with the aim of emancipating the citizenry and eradicating poverty in the long run, a lot still needs to be done. It is noteworthy that a quality and responsive education alone may not eradicate poverty instantaneously and directly, but it would work together with other subsectors towards alleviating it. Education however has the advantage of being able to empower and change the mind-set which is a prerequisite for meaningful economic development. Education, too, has the ability to bring about meaningful transformations, hitherto unknown.

\subsection{Recommendations}

In view of the aforementioned challenges and barriers the following suggestions are made:

- Quality should be guaranteed in both private and public schools for education to act as a driver of economic change and empowerment. Provision and maintenance of access, equity and retention should be prioritized as well.

- Poor parents should be helped to provide subsistence for their children, for 
example, provision of lunch and transport, to keep the learners at school and help break the cycle of poverty in the extremely poor households.

- Urgent need for expansion of physical and structural facilities to accommodate the large number of learners that were hitherto locked out of school due to inability to raise fees and other school levies.

- Provision of cash transfers and other monetary stipends to extremely poor households by the government to enable the families purchase basic needs and also help reduce the gap between the rich and the poor.

- Employment of more trained teachers to alleviate the staffing shortage in public schools and improve the teacher student ratio and also close the gap between private and public schools by ensuring that learning resources and materials match the number of students enrolled.

\section{Conflicts of Interest}

The authors declare no conflicts of interest regarding the publication of this paper.

\section{References}

Akoojee, S., \& McGrath, S. (2016). Post-Basic Education and Training and Poverty Reduction in South Africa: Progress to 2004 and Vision to 2014. Post-Basic Education and Training Working Papers Series No. 2 October 2005, Edinburgh: Centre of African Studies, University of Edinburgh.

Aseyo, O. (2015). Immediate Assessment of the Introduction of Free Secondary Education in Kenya. Emerging Issues, Oxford: Centre for International Education, University of Sussex.

Avenstrup, R., Liang, X., \& Nellemann, S. (2004). Kenya, Lesotho, Malawi and Uganda: Universal Primary Education and Poverty Reduction. Washington DC: World Bank.

Bregman, J., \& Stallmeister, S. (2002). Secondary Education in Africa (SEIA): A Regional Study of the Africa Region of the World Bank. World Bank Regional Workshop in Mauritius on the Renewal of African Secondary Education. Mauritius: World Bank.

Carceles, B. G., Fredriksen, B., \& Watt, P. (2001). Can Sub-Saharan Africa Reach the International Targets for Human Development? Africa Region Human Development Working Paper Series, Washington DC: The World Bank.

Deininger, K. (2003). Does Cost of Schooling Affect Enrolment by the Poor? Universal Primary Education in Uganda. Economics of Education Review, 22, 291-305. https://doi.org/10.1016/S0272-7757(02)00053-5

Echessa, H. (2017). Strategies Free Primary Education in Kenya. International Journal of Educational Development, 19, 318-329.

EFA (2013). Global Monitoring Report 2013/4-UNICEF, UNESCO.

Fielden, J. (2011). The Practice of Economic Inclusion: Managing International Activities in the UK. London: The UK HE International Unit. http://www.Universitiesuk.ac.uk

Gregoire, D. (2017). Economic Growth: Indicators and Parameters in Africa. Prague: School of Economics.

Gueye, A., \& Gauci, A. (2011). Pro-Poor Growth Strategies in Africa: Pro-Poor Education Policies and Labour Demand. In Expert Group Meeting, Munyonyo Speke Resort. United Nations Economic Commission for Africa. Economic Policy Research Center 
Addis Ababa: ( $)$ UN. ECA.

Hannon, C. (2012). Challenges for Teachers in Universal Secondary Education (USE). Brasque: Northern Point.

IPRSP (2000). Interim Poverty Reduction Strategy Paper. Washington DC: International Monetary Fund 2000-2003.

https://www.imf.org/external/NP/prsp/2000/ken/01/INDEX.HTM

Isaacs, S. (2002). It's Hot for Girls! ICTs as an Instrument in Advancing Girls' and Women's Capabilities in School Education in Africa. In Advancement of Women EXpert Group Meeting "Information and Communication Technologies and Their Impact on and Use as an Instrument for the Advancement and Empowerment of Women”. Seoul: Republic of South Korea. United Nations.

Kisinya, K. (2016). Free Primary Education. Nairobi: Bentos.

Lewin, K. M. (2004) Expanded Access to Secondary Schooling in Sub-Saharan Africa: Planning and Finance Issues. Create Pathways to Access Research Monograph No. 8, Brighton: University of Sussex.

Liang, X., Avenstrup, R., \& Nellemann, S. (2004). Kenya, Lesotho, Malawi and Uganda: Universal Primary Education and Poverty Reduction.

Lucas, A. M., \& Isaac, M. M. (2012). Access, Sorting, and Achievement: The Short-Run Effects of Free Primary Education in Kenya. American Economic Journal: Applied Economics, 4, 226-253. https://doi.org/10.1257/app.4.4.226

Malenya, F. L. (2008). The Free Secondary Education Agenda. In the Education Stakeholders'Symposium (p. 6). Nairobi: Kenya Institute of Education.

Ministry of Education, MoE (2009). The National Special Needs Education Policy Framework.

MoEST (2015). Education Sector Report. Nairobi: Ministry of Education.

MoEST (2018). The Education Agenda. Nairobi: Ministry of Education.

Mueni, J., \& Macho, S. (2016). Is Free Primary Education in Kenya Free? Understanding the Phenomenon, KRIP, Kenya.

Mulanda, T., \& Kosea, J. (2018). Liberating Effect. Kampala: Munnion.

Mulinya, C. L., \& Orodho, A. J. (2015). Free Primary Education Policy: Coping Strategies in Public Primary Schools in Kakamega South District, Kakamega County, Kenya. Journal of Education and Practice, 6, 162-172.

Musomi (2018). Poverty as a Function of Education Strategies and Realities. Journal of International Education, No. 1-4, 292-301.

Muteshi, S. (2016). Barriers to Development: Resources, Policy. Kampala: Rapporteur.

Mutua \& Ochieng (2018). Poverty and Its Implications: Three Cases Globalisation. Beham, Nairobi.

Mwangi, L. (2013). Special Needs Education (SNE) in Kenyan Public Primary Schools: Exploring Government Policy and Teachers' Understandings. A Thesis Submitted in Fulfilment of the Requirements for the Degree of Doctor of Philosophy, London.

Nduka, K. (2015). Free Education Concerns. Unpublished Master's Thesis, Eldoret: Moi University.

Ngugi (2013). The Role of Basic Education in Development (p. 21). Education Magazine, 1992.

NPEP (1999). National Poverty Eradication Plan 1999-2015. Nairobi: Department of Development Coordination.

Ohba, A. (2012). Does Free Secondary Educations Enable the Poor to Gain Access? A 
Study from Rural Kenya. CREATE Pathways to Access Research Monograph No. 21, Brighton: University of Sussex.

Onyango, N., \& Muteshi, G. (2016). Secondary Education in Kenya: Costs and Options. Discussion Paper, Nairobi: Institute for Public Policy Research and Analysis.

Onyango, S. (2017). Poverty Keeps Children Out of School. Nairobi: Bima.

Orodho, J. A., Getange, K. N., \& Onkeo, J. M. (2014). Alternative Sources of Funding for Free Day Secondary Education (FDSE) in Public Schools in Kisii Central District, Kisii County, Kenya. IOSR Journal of Dental and Medical Sciences, 13, 14-23. https://doi.org/10.9790/0853-13461423

PPARs (1999). Participatory Poverty Assessment Report.

PRSP (2003). Poverty Reduction Strategy Paper. Washington DC: International Monetary Fund. https://doi.org/10.5089/9781451829976.002

PRSP (2005). Poverty Reduction Strategy Paper. Washington DC: International Monetary Fund. https://doi.org/10.5089/9781451821130.002

Psacharopoulos, G., \& Patrinos, A. (2002). Returns to Education: A Further Update. World Bank Policy Research Paper No. 2881, Washington DC: World Bank.

Rawat, R. (2017). The Association between Economic Development, Education and FGM in Six Selected African Countries. MAG Online Library.

Republic of Kenya (2010). Education Sector Report-KNQA.

Rono, K. Z. (2015). Challenges Facing the Implementation of Free Secondary Education in Ainamoi Division, Kericho County. Unpublished Master's Thesis.

UNESCO (2005). Challenges of Implementing Free Primary Education in Kenya: Assessment Report. Nairobi: Ministry of Education, Science and Technology.

UNESCO (2014). World Conference on Sustainable Development. Nagoya. https://unesdoc.unesco.org/search/N-EXPLORE-47c78c52-7803-4518-ae22-cd9e28b7f3 01

UNESCO (2017). Education Transforms Lives. http://www.unesco.org

UNESCO (2020). Global Education Mentoring Report Team (Gem Report) World Education Blog.

UNICEF (2009). Abolishing School Fees in Africa Lessons from Ethiopia, Ghana, Kenya, Malawi, and Mozambique.

UNICEF and World Bank (2005). Africa Human Development Series, Development Practice in Education. Washington DC: World Bank.

United Nations (2013). A New Global Partnership: Eradicating Poverty and Transform Economy through Sustainable Development. The Report of the High-Level Panel of Eminent Persons on the Post 2015 Development Agenda, New York: The United Nations.

World Bank (2018). Poverty Incidence in Kenya Declined Significantly, But Unlikely to be Eradicated by 2030. Washington DC: World Bank. 